\title{
POTENTIAL OF NEW TECHNOLOGIES IN PROVIDING EFFICIENCY OF PEDAGOGICAL CONTROL IN PHYSICAL EDUCATION
}

\author{
Victor Koryahin ${ }^{1}$, Oksana Blavt ${ }^{1}$, Oleksandra Vanivska ${ }^{2}$, Volodymyr Stadnyk ${ }^{1}$ \\ ${ }^{1}$ Lviv Polytechnic National University \\ ${ }^{2}$ Ukrainian National Forestry University
}

Corresponding author: Oksana Blavt: oksanablavt@ukr.net

Accepted for Publication: March 20, 2020

Published: March 25, 2020

\section{DOI: $10.17309 / \mathrm{tmfv.2020.1.04}$}

\begin{abstract}
The study objective is to substantiate and implement modern electronic automated monitoring systems to improve the testing of speed-strength abilities in the process of physical education.

Materials and methods. To solve the research tasks used the methods of comparing and contrasting are used and analysis, synthesis, abstraction, formalization and technical modeling.

Results. The developed capacitive sensor device for control of speed-power abilities is presented. The device is built on a combination of modern nanotechnology and microprocessor systems. As part of the device, the array of active electrodes with digital output registers an input signal from a marker placed on the monitoring object and whose position changes during the exercise. Then the digital signal through the interface and the communication line, goes to the signal converter, where it is processed and wireless transmission devices signal goes to the personal computer, where the result of the exercise is displayed. Conclusions. Use in pedagogical control of the physical education process of the developed device provides reliable objective test data with little loss of time to ensure the quality of control.
\end{abstract}

Keywords: control, testing, monitoring, speed and power abilities, sensor device.

\section{Introduction}

Problem statement. A rational qualitative approach to the process of physical training provides for a constant assessment of the adequacy of a specific training program and ensuring a quick correction of the inconsistency (Ivashchenko, 2016). The current pedagogical control of the dynamics of physical fitness is considered as the main component of the management of physical training in the process of physical training, which is the basis for further planning (Preatoni, Hamill, Harrison, Hayes, Van Emmerik, Wilson, \& Rodano, 2013).

Effective management of the physical preparation process implies possession of objective and reliable information on the dynamics of indicators of the level of physical fitness. Questions of pedagogical testing physical fitness - one of the most relevant theory and methodology of physical education (Anikieiev, 2015; Alfrey, \& Gard, 2014; Magill, 2007).

Analysis of recent research and publications. Numerous scientific sources (Lauber, \& Keller, 2014; Reiman, \& Manske, 2009; Tanner, \& Gore, 2012) are devoted to the management of the training process in the field of physical culture on the basis of monitoring the state and level of special physical fit-

(C) Viktor Koryahin, Oksana Blavt, Oleksandra Vanivska, Volodymyr Stadnyk, 2020. ness. However, this problem is still a matter of debate. The fact that the basis for the growth results of physical training lies in the improvement of means and methods for the development of physical qualities, as well as the current pedagogical control of this process is undoubted (Hardman, \& Green, 2011; Stroot, 2014; Schmidt, \& Wrisberg, 2008).

One of the problems facing researchers in the field of physical education is the need for a radical restructuring of the pedagogical control system in the direction of its modernization, the introduction of innovative approaches, and modern technologies of organization a testing (Silverman, Keating, Phillips, 2008; Koryahin, Blavt, \& Ponomaryov, 2019; Purcell, Channells, James, \& Barrett, 2005). Ensuring a high level of physical fitness, which is one of the important subjects of study of many studies, determines the high relevance of finding ways to improve testing methods. Given the above, the development of tools and methods of test in pedagogical control is a powerful means of improving the effectiveness of the training process (Bassett, 2000; Koryagin, \& Blavt, 2019; Tanner, \& Gore, 2012). Given that the most relevant topic for discussion in science today is the topic of innovation, let us note the discreet consideration of these issues in the current scientific literature, which requires studies of adaptation and introduction of new information services, which can not be considered relevant and promising. 
One of the most informative indicators of physical condition is considered by specialists as speed-power abilities (Edwards, 2010; Lauber, \& Keller, 2014). In the system of physical training, power abilities are the most multicomponent in their structure and dimension compared to other physical qualities. Their high level is practically necessary to maintain a high level of performance in the process of physical culture (Lauber, \& Keller, 2014; Wulf, \& Lewthwaite, 2009).

Speed-power abilities manifest themselves in actions where, along with force, high speed of movement is required (athletics jumps and throwing, sprint, boxing, barbell jerk, etc.) (Mikolajeca, Waskiewicza, Maszczykb, Bacikc, Kurekd, \& Zaja, 2012). They are characterized by unsatisfied muscle tensions, manifested with the necessary, often maximum power in exercises performed with considerable speed, but not reaching, as a rule, the limiting value. Speed-power abilities are manifested in the ability to perform movement in the shortest possible period of time and under conditions when there is an active opposition to this. These forceful countermeasures include: overcoming the strength and severity of body weight (Ivashchenko, 2016; Stroot, 2014; Mac-Duggala, 1997).

The development of speed-power abilities in the studies of reputable scientists is given a lot of attention, since they are the scientific basis for understanding and practical solution of certain issues in physical training (Lauber, \& Keller, 2014; Magill, 2007; Stroot, 2014). Among the necessary conditions that ensure their improvement, it is important to study the dynamics of their development, which requires the creation of an optimal method of control (Crocker, \& Algina, 2015; Shumway-Cook, \& Woollacott, 2007; Hardman, \& Green, 2011).

Analysis of practical and theoretical studies of the issue under study (Bassett, 2000; Edwards, 2010; Koryagin, \& Blavt, 2019) shows the existing contradictions between the need to ensure the objectivity of testing and the inability to do this. It should be noted that in theory and practice of physical culture and sports, issues related to the information content of the procedure for testing the dynamics of speed-power abilities are not sufficiently developed, which is recognized by many scientists (Crocker, \& Algina, 2015; Wulf, \& Lewthwaite, 2009; Reiman, \& Manske, 2009).

The need to find ways to improve the methods of testing speed-power abilities led to the choice of the topic and direction of research. We believe that the development of new tools, methods and technologies based on modern achievements of electronic equipment is one of the most important and most promising areas for improving the testing process.

Purpose of the research is to substantiate and implement modern electronic automated monitoring systems to improve the testing of speed-strength abilities in the process of physical education.

\section{Materials and methods}

To solve the research tasks used the methods of comparing and contrasting are used and analysis, synthesis, abstraction, formalization and technical modeling. The research strategy is focused on the integration of the information resource of newest electronic technologies to ensure the effectiveness of control in the process of physical education. Our innovative idea envisaged the integration of interdisciplinary and project-based approaches. The research strategy was focused on the integration of information resources for effective control. We aimed to intensify the pedagogical process of control, which greatly enhances its informative capabilities. Informatisation in monitoring in the context of our study was to build the infrastructure of means of receiving, storing, accumulating and processing information. This presumed the creation of a breakthrough compute-ahead device for controlling speed-strength abilities, whose work was focused on ensuring the effectiveness of testing, enriching the control information data and enhancing the results.

Technical simulation used to create instruments to be studied (Estivalet, \& Springer, 2009). In this case, the use of technical means further modeling is experimental in nature.

Technical modeling based on the elements of prediction, please be based on the results, which at the time of the decision is still unknown, used to obtain new knowledge about the object under study. This is realized on the basis of the study of ego conditionally description, basic parameters and predictability of properties, implementation and their manifestation in practice, which is an objective practical criterion test our knowledge. As an effective scientific method, the application of theoretical logic modeling, based on conceptual ideas and symbolism, provides clear identification, analysis and rationalization of the use of development tools (Magill, 2007; Edwards, 2010). The result of these representations is us in the form of a structural diagram.

\section{Results}

To determine the level of speed-strength abilities used a variety of control exercises. At present, it is most often proposed to use the "jump" test - jumping up (with and without a measuring tape): moving the body or its individual segments in space in a relatively short time (Tanner, \& Gore, 2012).

To control the height of jumping without a measuring tape, a graduated board is used, which is mounted on the wall. The subject of monitoring is standing, touching the board as high as possible. Next, jumps vertically up and touches the markup again. The distance between two touch points is an

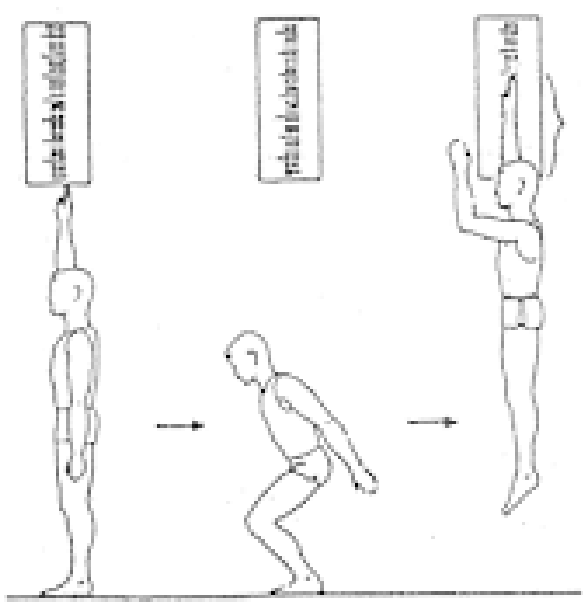

Fig. 1. Determination of jump height without measuring tape 

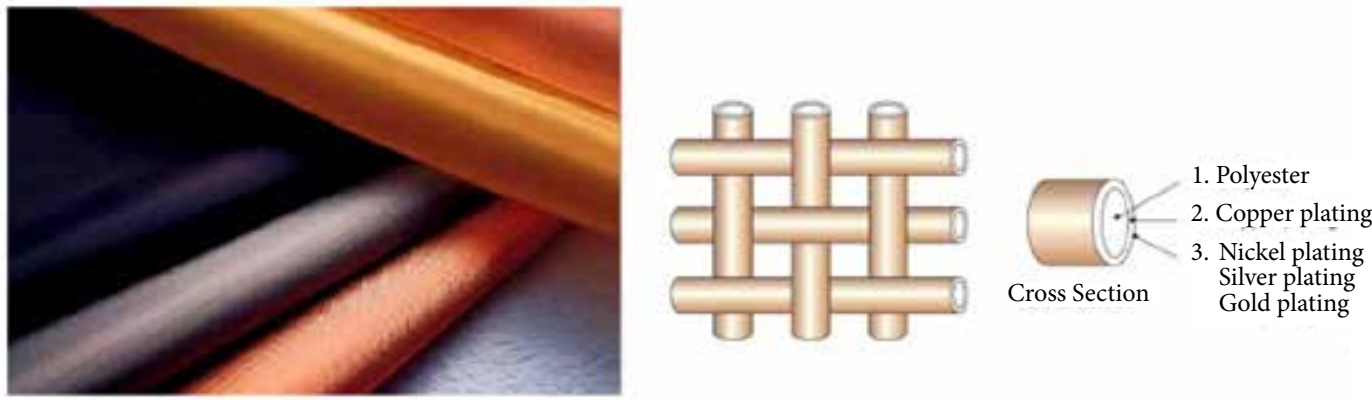

Fig. 2. Structure of the metallized fabric

estimate of the height of the jump. The same test also measures speed-power endurance: a series of jumps are performed at intervals of 3 seconds. Quantitative assessment of the test is carried out by ergometric analysis, which allows to obtain a number of indicators characterizing the speed-strength endurance: the maximum jumping height and the number of jumps performed with the maximum height.

The difficulty of this test lies in the need for strict standardization of the standing position - stand facing the board with the hands as high as possible, as well as squatting: the position when the angle at the knee joint is 90 degrees, which can be standardized only by using an electro-goniometer.

Jumping out with a measuring tape consists of using a device that is an elastic clip, tightly attached to the floor. The methodical feature of this test is that the subject, after jumping, must land in a square measuring $40 \times 40 \mathrm{~cm}$, which makes it difficult to carry out the test (Mac-Duggala, 1997).

Accordingly, given the objective difficulties in conducting the test, there is a certain dependence of the subjective assessment of the perception of compliance with the necessary body position, which is established visually during the monitoring. There is a probability of error in the reliable assessment of the results of the test exercise. Accordingly, they cannot testify to the effectiveness of the used means of the training process.

To create an automated system for testing the parameters of speed-power abilities, we have developed a capacitive sensor monitoring device, which is based on a combination of modern nanotechnology and microprocessor systems, in particular, smartphones, tablet computers, etc. The basis of the capacitive sensor monitoring device is an electronic measuring system of the spatial position of objects based on capacitive sensing devices (Hotra, Mykytyuk, \& Sushynskyy, 2010).

Sensory devices are one of the most dynamically developing classes of modern electronics (Baxter, 1997). Modern microsensorics, as the formed direction of development of electronic means for measuring parameters of physical quantities, combines traditional measuring equipment, solid-state electronics, circuit technology and microprocessor technology. One of the most progressive classes of sensor devices is capacitive type sensors. The informative signal of such sensors is the capacitance between the electrodes, which changes under the influence of external factors. Such a factor is the distance between the moving body of the monitoring object and the system of stationary electrodes. A significant advantage of capacitive type sensors is the non-contact measurement process, which ensures high ergonomics of the capacitive sensor monitoring device (Haake, 1996; Hotra, Mykytyuk, \& Sushynskyy, 2010).

To create electrodes in these devices, "intelligent textiles", which is made using nanofibers, is used. The latter are made by filling traditional fiber polymers with nanoparticles of conductive materials, which ensures their high elastic and electrical characteristics. One of the most promising materials are carbon nanotubes. The electrical conductivity of the fibers filled with them is comparable to copper, and the mechanical stability with steel. At the same time, the specific weight of nanotubes is hundreds of times less than in traditional materials.

The manufacture of conductive fabrics has already been mastered by industry, in particular, Hana Elecom manufactures a wide range of flexible metallized fabrics (Fig. 2), adhesive tapes can be applied on traditional fabrics, as well as a variety of flexible profiles, gaskets, etc. The basis fabric is polyester fibers (Polyester), whose surface is covered with ultrathin layers of copper, nickel or gold (Copper, Nickel, Gold plating) (Koryagin, \& Blavt, 2019).

To ensure the reliability of the test results and the objectivity of monitoring in the high jumps, an capacitive sensor monitoring device was formed. The structure of which includes: capacitive electrodes (active and passive), a signal line, a signal converter, an interface, a communication line and a mobile communication system, in particular, a smartphone or tablet computer.

A one-dimensional matrix of active strip capacitive electrodes is glued to the indicator wall (Fig. 3). The active electrodes are connected to the signal transducer by a signal line (cable harness). A passive electrode in the form of a marker, placed on the subject of monitoring, is contactless, which ensures the absence of cables between this electrode and the signal converter.

The signal converter provides switching of a matrix of capacitive electrodes to one analog information input and conversions such as "capacitance of an electrode - a digital code". Further, the digital signal is transmitted via the interface (in this embodiment, the USB interface) and the communication line, in particular, the infrared or radio frequency bands, is transmitted to the mobile communication system, where it is recorded and graphically visualized.

In the system for measuring the jump parameters, the matrix of capacitive electrodes generates a set of signals that can be used to monitor the highest and lowest points of the body of the monitoring subject, the position of body parts 


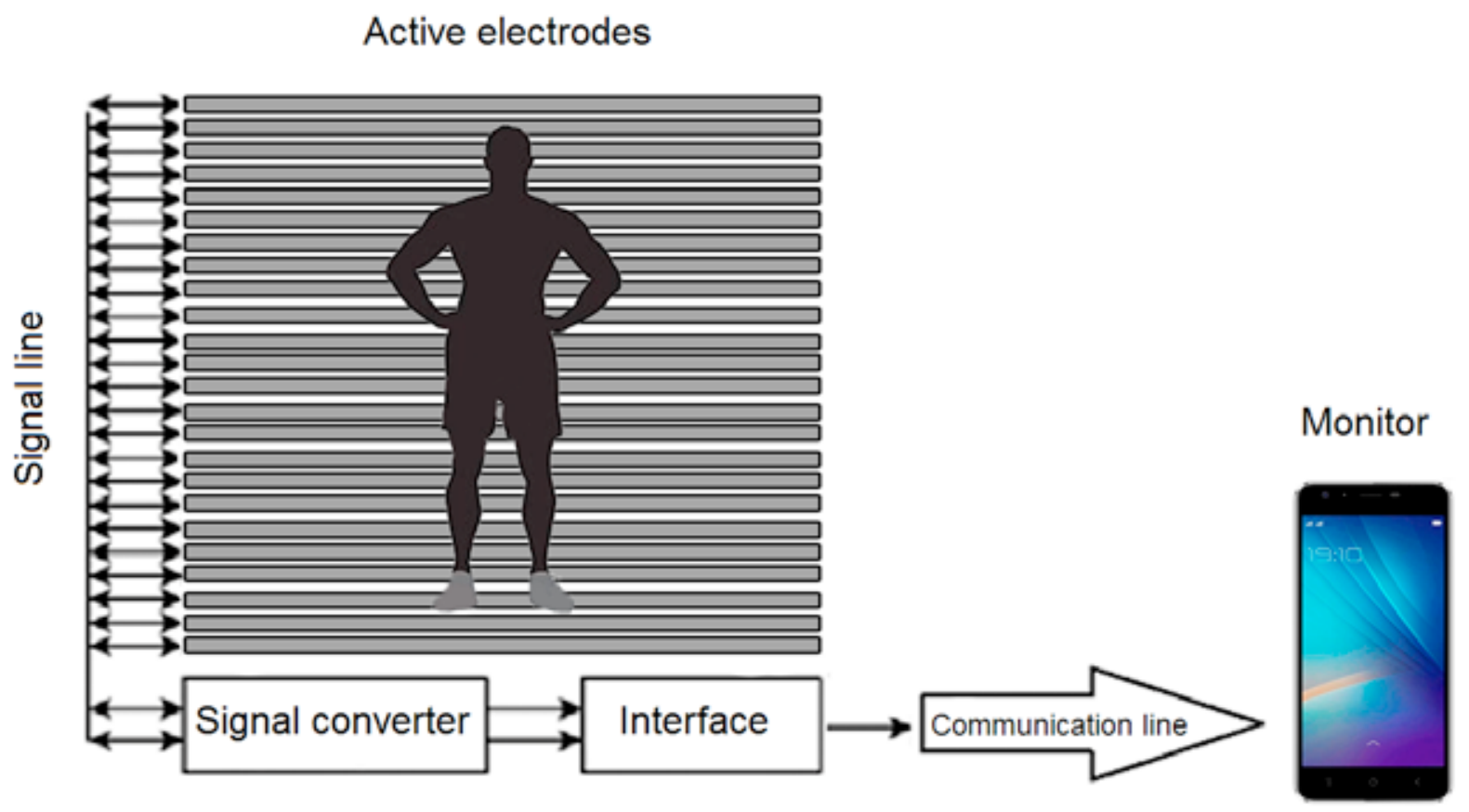

Fig. 3. Structural diagram system for measuring the jump parameters

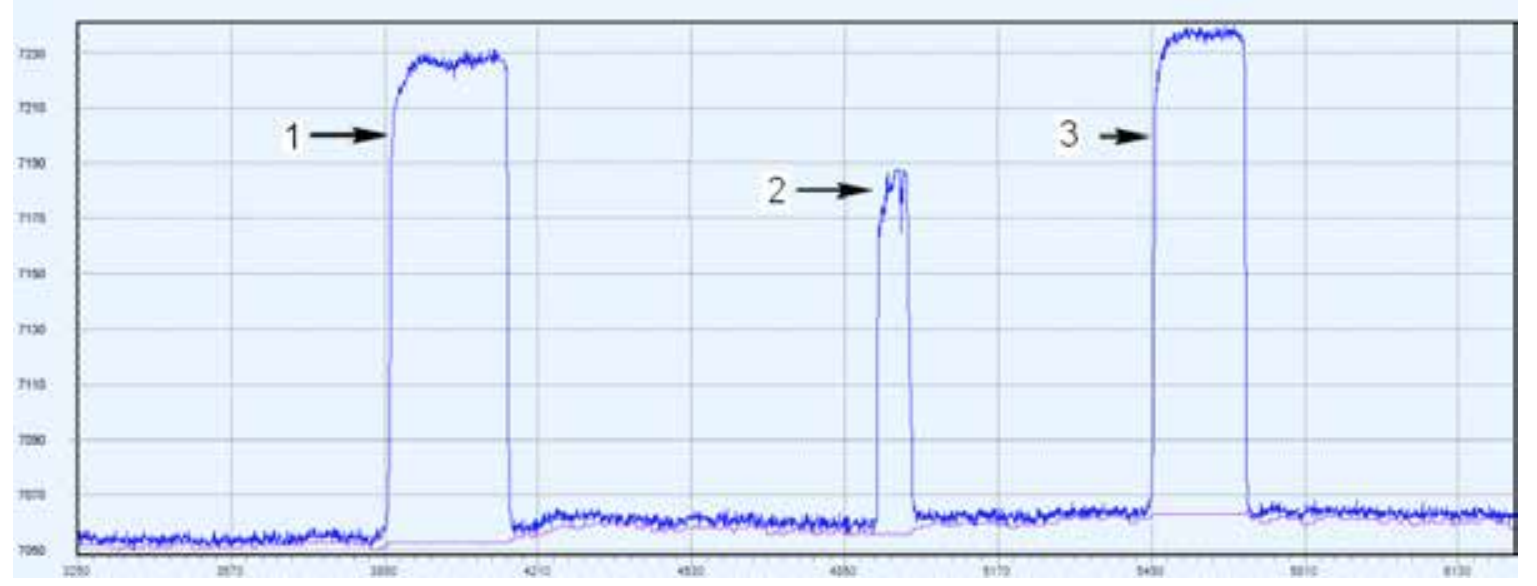

Fig. 4. An example of a waveform when performing a test exercise

and movement dynamics (with a time resolution of $0.01 \mathrm{~s}$ ). Electrodes in the form of flexible conductive tapes are glued to the indicator wall, up to $3 \mathrm{~m}$ high. The width of the tapes and the distance between them is $5 \mathrm{~mm}$, which determines the resolution of the spatial position measurement, in particular above the floor level, of the monitoring subject.

The signal converter is implemented on the PSoC integrated circuit - a programmable system on a chip from $\mathrm{Cy}$ press (Koryagin, \& Blavt, 2019). An example of a waveform and its boundaries are shown in Fig. 4, where it is shown: 1, $2,3-$ the signal.

The developed method of estimating the speed-power abilities is that the matrix of active electrodes with a digital output registers the incoming signal from a marker placed on the subject of monitoring and whose position changes during the exercise. The matrix registers the start of the exercise, the process of completion and the end of the exercise. Next, the digital signal through the interface and the communication line enters the signal converter, where it is processed. Next, wireless devices transmit information through a signal to an electronic computing device, which they use to monitor the exercise and, by the value of which, they make a conclusion about the state of speed-power abilities.

The advantages of the developed method include the combination of such properties as:

- the comfort of the examination, which excludes the special preparation of the subject of monitoring for attaching electrodes or sensors on it during its examination;

- a short survey time, which consists of the information retrieval time (usually within 20-60 seconds) and the time for viewing the obtained data and analyzing the processing results, which does not exceed 1-2 minutes during mass surveys; but it can be im- 
plemented and monitoring, that is, long-term observation with the update of the processing results after a specified time interval;

- information content of the survey;

- $\quad$ high confidence level;

- multifunctionality, allowing to use the technique as a diagnostic tool for wide control and training of speed-power abilities;

- ease of implementation.

The introduction and use of modern electronic technologies in the test process in the field of physical culture and sports is a powerful methodological basis for its continuous, scientifically grounded, targeted correction based on an integral approach to the development of physical qualities, which allows achieving a qualitative improvement in the training process.

\section{Discussion}

We fully support the scientific approaches of specialists engaged in finding ways to optimize physical education results (Ivashchenko, 2016; Schmidt, \& Wrisberg, 2008; Shumway-Cook, \& Woollacott, 2007). In this context, we are joining the idea that the efficiency of this process can be greatly enhanced by adjusting the pedagogical control. The results of our study are consistent with a number of scientific advances on the expedient implementation of controls in physical education that regulate the appropriateness of pedagogical effects to ensure the effectiveness of physical education (Bassett, 2000; Matiegka, 1991; Stroot, 2014; Wulf, \& Lewthwaite, 2009).

Our research corroborates the studies (Clarys, \& Cabri, 1993; Shepard, \& Janky, 2008; Kavanagh, \& Menz, 2008) which postulate that the automation of the process for obtaining and processing information of testing can significantly improve the efficiency of obtaining and evaluating information in real time and significantly reduce time spent on conducting tests.

The use of modern electronic technologies in the testing ensures the accuracy of the presentation of the measurement information and the correspondence between the degree of scientific reliability and the practical value of the results. This corroborates our own scientific research results in the given domain (Koryahin, \& Blavt, 2018; Koryahin, Blavt, \& Ponomaryov, 2019; Koryahin, Mukan, Blavt, \& Virt, 2019).

The results of the study supplement the data on pedagogical assessment in physical education. We are of the opinion that using the potential of modernization in the modern scientific space, it is possible to significantly increase the informatization of physical training by using the latest technologies in the implementation of pedagogical control (Capobianco, Almuklass, \& Enoka, 2018; Koryahin, Blavt, \& Ponomaryov, 2019; Purcell, Channells, James, \& Barrett, 2005; Kavanagh, \& Menz, 2008).

The scientific novelty of the results of this research is that for the first time the software of assessment of speed-strength abilities in the physical education, developed on the basis of modern electronic technologies, is presented.

The results of the study complement the information on pedagogical control in physical education (Anikieiev, 2015; Alfrey, \& Gard, 2014; Jrgensen, Andersen, Froberg, Maeder, von Huth Smith, \& Aadahl, 2009; Ivashchenko, 2016; Koryahin, Mukan, Blavt, \& Virt, 2019).
Information on the practical use of the latest technologies to ensure modern advances in the theory and methodology of physical education has been supplemented (Edwards, 2010; Estivalet, \& Springer, 2009; Koryahin, Blavt, \& Ponomaryov, 2019). We support scientific approaches (Mac-Duggala, 1997; Strohrmann, Harms, Kappeler-Setz, \& Troster, 2012; Wulf, \& Lewthwaite, 2009) that such a strategy provides quality control of the lead character, which will greatly improve the quality of testing and control results obtained and provide a transition to a new level of effectiveness.

\section{Conclusions}

Improving the quality of the training process is possible through the development and implementation of special electronic-technical devices for the implementation of automated monitoring of special physical fitness. The proposed method for estimating speed-power abilities is based on the latest achievements of electronic equipment, which provides reliable data with insignificant loss of time. The scientific potential of the technical equipment of the testing process in the process of physical training allows for a sufficiently high level to monitor and evaluate these indicators.

An objective assessment of the development of speedstrength parameters of physical fitness allows you to comprehensively solve current control issues, make timely adjustments during classes according to the results obtained and, thus, ensure that the optimal strategy for the training process is selected through its targeted correction.

The presented results of the work can be qualified as a significant contribution in the field of physical education in the context of modernization of this process in the context of integration of Ukraine into the European space. The realization of innovations is a testament to their real value, an indicator of relevance and effectiveness, which are manifested in concrete, qualitatively new results of physical education. Further research is planned in the direction of the development of automated technologies for the reorganization of other test samples for the organization of clear control in the field of physical culture.

\section{Conflict of interest}

The authors state no conflict of interest.

\section{References}

Aadahl, M. \& Jorgensen, T. (2003). Validation of a new self-report instrument for measuring physical activity. Medicine and Science in Sports and Exercise, 35, 1196-1202. https://doi.org/10.1249 /01. MSS.0000074446.02192.14

Anikieiev, D.M. (2015). Criteria of effectiveness of students' physical education system in higher educational establishments. Physical education of students, 5, 3-8. https://doi.org/10.15561/20755279.2015.0501

Alfrey, L., \& Gard, M. (2014). A crack where the light gets in: a study of Health and Physical Education teachers' perspectives on fitness testing as a context for learning about health. Asia-Pacific Journal of Health, Sport and Physical Education, 5(1), 3-18. https://doi.org/10.1080/183 77122.2014 .867790 
Alme, K.J., \& Mylvaganam, S. (2006). Electrical Capacitance Tomography: Sensor Models, Design, Simulations, and Experimental Verification IEEE. Sensors Journal, 6(5), 1256-1266. https://doi.org/10.1109/JSEN.2006.881409

Bassett, D.R. (2000). Validity and reliability issues in objective monitoring of physical activity. Research Quarterly for Exercise and Sport, 71, 30-36. https://doi.org/10.1080/0270 1367.2000.11082783

Baxter, L.K. (1997). Capacitie sensors: design and application. IEEE Press.

Bracke, W., Puers, R., \& Van Hoof, C. (2007). Ultra low power capacitive sensor interfaces. Springer.

Clarys, J.P., \& Cabri, J. (1993). Electromyography and the study of sports movements: A review. Journal of Sports Sciences, 11(5), 379-448. https://doi. org/10.1080/02640419308730010

Capobianco, R.A., Almuklass, A.M. \& Enoka, R.M. (2018). Manipulation of sensory input can improve stretching outcomes. European Journal of Sport Science, 18(1), 83-91. https://doi.org/10.1080/17461391.2017.1394370

Chow, G.C.C., Chung, J.W.Y., Ma A.W.W, Macfarlane, D.J., \& Shirley, S.M.F. (2017). Sensory organisation and reactive balance control of amateur rugby players: A crosssectional study. European Journal of Sport Science, 17(4), 400-406. https://doi.org/10.1080/17461391.2016.1257656

Crocker, L., \& Algina, J. (2015). Introduction to Classical and Modern Test Theory. New-York: Harcourt Brace Jovanovich.

Geoffrey, A., Power, G., Handrigan, A., Basset, F.A. (2012). Ventilatory response during an incremental exercise test: A mode of testing effect. Pedagogy, 12(6), 491-498. https://doi.org/10.1080/17461391.2011.573580

Edwards, W.H. (2010). Motor Learning and Control From Theory to Practice. California: Wadsworth.

Estivalet, M., \& Springer, P. (2009). The Engineering of Sport. Paris: Springer-Verlag.

Jrgensen, T., Andersen, L.B., Froberg, K., Maeder, U.L., von Huth Smith, \& Aadahl, M. (2009). Position statement: Testing physical condition in a population - how good are the methods? European Journal of Sport Science, 9(5), 257267. https://doi.org/10.1080/17461390902862664

Haake, S. (1996). The engineering of sport. Taylor \& Francis.

Hardman, K, \& Green, K. (2011). Contemporari issues in phisical education. Mayer \& Mayer Verlag.

Hotra, Z., Mykytyuk, Z, \& Sushynskyy, O. (2010) Sensor systems with optical channel of information transferring. Przeglad Elektrotechniczny, 86(10), 21-23. https://doi.org/ bwmeta1.element.baztech-article-BPOM-0032-0006

Ivashchenko, O.V. (2016). Pedagogical control of motor and functional fitness of girls 15-16 years. Teoria ta Metodika Fizičnogo Vihovanna, (3), 36-50. https://doi.org/10.17309/ tmfv.2016.3.1171 (in Ukrainian).

Ivashchenko, O. \& Khudolii, O. (2016). Methodological approaches to pedagogical control in the process of physical education of girls 12-14 years old. Teoria ta Metodika Fizičnogo Vihovanna, (4), 13-24. https://doi. org/10.17309/tmfv.2016.4.1175 (in Ukrainian).
Kavanagh, J.J., \& Menz, H.B. (2008). Accelerometry: A technique for quantifying movement patterns during walking. Gait \& Posture, 28(1), 1-15. https://doi. org/10.1016/j.gaitpost.2007.10.010

Koryagin, V., \& Blavt, O. (2019). Innovative test control technologies in physical education and sports: a monograph. Lviv, Ukraine: Lviv Polytechnic Publishing House, 236.

Koryahin, V., \& Blavt, O. (2018). The Use of Information and Communication Technology for Determining the Level Mobility in Joint in Physical Education of Students. Teoria ta Metodika Fizičnogo Vihovanna, 18(3), 107-113. https:// doi.org/10.17309/tmfv.2018.3.01

Koryahin, V., Blavt, O., \& Ponomaryov, S. (2019). Innovative Intestification of Testing of Strength Endurance in Physical Education of Students With Chronic Diseases. Teoriâ ta Metodika Fizičnogo Vihovannâ, 19(3), 116-122. https://doi.org/10.17309/tmfv.2019.3.02

Koryahin, V., Mukan, N., Blavt, O., \& Virt, V. (2019). Students' coordination skills testing in physical education: ICT application. Information Technologies and Learning Tools, 70(2), 216-226. https://doi.org/10.33407/itlt.v70i2

Lauber, B., \& Keller, M. (2014). Improving motor performance: Selected aspects of augmented feedback in exercise and health. European Journal of Sport Science, 14(1), 36-43. https://doi.org/10.1080/17461391.2012.725104

Magill, R.A. (2007). Motor learning and control: Concepts and applications (8th ed.). McGraw-Hill International Edition.

Matiegka, J. (1991). The testing of physical efficiency. Amer. Journal of Physical Anthropology, 4(3), 125-134. https://doi. org/10.1002/ajpa.1330040302

Mero, A., Komi, P.V., \& Gregor, R.J. (1992). Biomechanics of sprint running. Sports Medicine, 13(6), 376-392.

Neville, J., Wixted, A., Rowlands, D., \& James, D.(2010). Accelerometers: An underutilized resource in sports monitoring. Sixth International Conference on Intelligent Sensors, Sensor Networks and Information Processing (ISSNIP), Brisbane, Australia, 287-290.

Nashner, L.M. (1997). Computerized dynamic posturography. St. Louis, MO: Mosby Yearbook.

Reiman, M.P., \& Manske, R.C. (2009). Functional testing in human performance. Champaign IL : Human Kinetics.

Physiological testing of high-class athlete / ed. J. D. Mac-Duggala [et al.]. (1997). Kiev: Olympic literature. (in Russia).

Preatoni, E., Hamill, J., Harrison, A.J., Hayes, K., Van Emmerik, R., Wilson, C. \& Rodano, R. (2013). Movementvariability and skills monitoring in sports. Sports Biomechanics, 12(2), 69-92. https://doi.org/10.1080/14763141.2012.738 700

Purcell, B., Channells, J., James, D., \& Barrett, R. (2005). Use of accelerometers for detecting foot-ground contact time during running. Proceedings of SPIE, 6036(603615), 1-8.

Schmidt, R.A., \& Wrisberg, C.A. (2008). Motor Learning and Performance: A Situation-based Learning Approach. (I. Champaign, Ed.). Human Kinetics.

Silverman, S., Keating, X.D., Phillips, S.R. (2008). A lasting impression: A pedagogical perspective on youth fitness testing. Measurement in Physical Education 
and Exercise Science, 12,146-166. https://doi. org/10.1080/10913670802216122

Shepard, N.T., \& Janky, K. (2008). Background and technique of computerized dynamic posturography. San Diego, CA: Plural.

Shumway-Cook, A., \& Woollacott, M.H. (2007). Normal postural control. Motor control: Translating research into clinical practice (3rd ed.). Philadelphia, PA: Lippincott Williams and Wilkins.

Stroot, S.A. (2014). Case Studies in Physical Education: Real World Preparation for Teaching. Routledge.

Stetter, B.J., Buckeridge, E., Nigg, S.R., Sell, S. \& Stein, T. (2019). Towards a wearable monitoring tool for in-field ice hockey skating performance analysis. European Journal of Sport
Science, 19(7), 893-901. https://doi.org/10.1080/17461391 .2018 .1563634

Strohrmann, C., Harms, H., Kappeler-Setz, C., \& Troster, G. (2012). Monitoring kinematic changes with fatigue in running using body-worn sensors. IEEE Transactions on Information Technology in Biomedicine, 16(5), 983-990. https://doi.org/10.1109/TITB.2012.2201950

Tanner, R., \& Gore, C. (2012). Physiological Tests for Elite Athletes Second. Edition Human Kinetics, Inc.; Second edition.

Wulf, G. \& Lewthwaite, R. (2009). Conceptions of Ability Affect Motor Learning. Journal of Motor Behavior, 41(5), 461467. https://doi.org/10.3200/35-08-083

\title{
ПОТЕНЦІАЛ НОВІТНІХ ТЕХНОЛОГІЙ У ЗАБЕЗПЕЧЕННІ ЕФЕКТИВНОСТІ ПЕДАГОГІЧНОГО КОНТРОЛЮ У ФІЗИЧНОМУ ВИХОВАННІ
}

\author{
Віктор Корягін ${ }^{1}$, Оксана Блавт ${ }^{1}$, Олександра Ванівська ${ }^{2}$, Володимир Стадник $^{1}$ \\ ${ }^{1}$ Національний університет «Львівська політехніка» \\ ${ }^{2}$ Національний лісотехнічний університет України \\ Реферат. Стаття: 7 с., 4 рис., 30 джерел.
}

Мета дослідження - обгрунтування та реалізація новітніх технологічних засобів для вдосконалення тестування швидкісно-силових здібностей у процесі фізичного виховання.

Матеріали та методи. Для вирішення завдань дослідження використано методи порівняння аналізу, синтезу, абстракції, формалізації і технічного моделювання.

Результати. Представлено розроблений ємнісний сенсорний пристрій для контролю швидкісно-силових здібностей. Пристрій побудований на поєднанні сучасних нанотехнологій та мікропроцесорних систем. У складі пристрою матриця активних електродів 3 цифровим виходом реєструє вхідний сигнал від маркера, розміщеного на об’єкті моніторингу і положення якого змінюється під час вправи. Далі цифровий сигнал через інтерфейс і лінію зв’язку надходить на сигнальний перетворювач, де обробляється й бездротовими пристроями передачі сигнал потрапляє на персональний комп'ютер, де результат вправи подається на дисплей.

Висновки. Використання розробленого пристрою у педагогічному контролі процесу фізичного виховання забезпечує отримання достовірних об'єктивних даних тестування з незначною втратою часу задля забезпечення якості контролю.

Ключові слова: контроль, тестування, моніторинг, швидкісні та силові здібності, сенсорний пристрій.

\section{Information about the authors:}

Koryahin V.: koryahinv@meta.ua; https://orcid.org/0000-0003-1472-4846; Lviv Polytechnic National University, Bandera, St, 12, Lviv, 79013, Ukraine

Blavt O.: oksanablavt@ukr.net; https://orcid.org/0000-0001-5526-9339; Lviv Polytechnic National University, Bandera St, 12, Lviv, 79013, Ukraine.

Vanivska O.: vanivskaoleksandra@gmail.com; http://orcid.org/0000-0003-0750-3949; Ukrainian National Forestry University, General Chuprynky St, 103, Lviv, 79057, Ukraine.

Stadnyk V.: vova121212131313@ukr.net; https://orcid.org/0000-0002-2864-4794; Lviv Polytechnic National University, Bandera St, 12, Lviv, 79013, Ukraine.

Cite this article as: Koryahin, V., Blavt, O., Vanivska, O., \& Stadnyk, V. (2020). Potential of New Technologies in Providing Efficiency Of Pedagogical Control In Physical Education. Teoriâ ta Metodika Fizičnogo Vihovannâ, 20(1), 25-31. https://doi. org/10.17309/tmfv.2020.1.04

Received: 26.01.2020. Accepted: 20.03.2020. Published: 25.03.2020

This work is licensed under a Creative Commons Attribution 4.0 International License (http://creativecommons.org/licenses/ by/4.0). 